\title{
INVESTIGATING THE ENCROACHMENTS IMPACT ON NILE RIVER HYDRODYNAMIC AND MORPHOLOGY
}

\author{
Ali, A. I. ${ }^{(1)}$; Moussa, A. M. ${ }^{(2)}$; El Mostafa, A. ${ }^{(1)}$ \\ and Girgis, Amira, F. A. ${ }^{(3)}$
}

1) Hydraulic and Irrigation Department, Faculty of Engineering, Ain Shams University.2) Nile River Institute, Ministry of Water Resource and Irrigation 3) Ministry of Water Resource and Irrigation

\begin{abstract}
In terms of the importance of protecting the Nile River in Egypt to satisfy the social and economic developments, this research was commenced with the main objective of investigating encroachment impacts on the flow characteristics and river morphology. Accustomed to the defined objectives, the research study phases (i.e. methodology) were designed to encompass 4 phases (i.e. theoretical, numerical investigation, analysis and inferential phases). This was achieved by implementing the available rating curves together with a 1-D model (GSTAR) and the hydrodynamics of the reach was investigated for different flood scenarios. Additionally, the 1-D model was tooled to estimate the morphological changes before and after encroachment at different flood scenarios.

Keywords: Nile River, reach four, hydraulic geometry, Morphology, Encroachment.
\end{abstract}

\section{INTRODUCTION}

The Nile River is the longest in the world that has a great significance to the Egyptians. It is divided into four reaches, according to its behavior. It runs from Aswan to Cairo, where it bifurcates into two branches Damietta and Rosetta to reach the Mediterranean Sea. The 4th reach is characterized by human activities interference (i.e. encroachment), which imposed negative impacts on its flow and morphology. Encroachment is an informal term for 
hydraulic analysis, which is achieved to evaluate the development impacts on the water surface elevation, river flow, morphology and river hydrodynamic. After 25th of January revolution and the security absence, the encroachment increased on this reach but the Ministry of Water Resource and Irrigation exerted a profound effort to remove those violations.

Natural rivers and alluvial canals are sensitive to human interference, which might change the sediment transport and flow rates. Human interference might take several forms (i.e. bank protection, dredging for navigation, bridge crossing and barrages). Side effects of man-induced development could be avoided if such interferences were properly designed and constructed. The Ministry of Water Resources and Irrigation is responsible for such a task in order to maintain the development policies that would maximize the use of the water resources. The Ministry prohibits encroachment of citizens to the Nile by applying law 12 of 1984 on Irrigation and Drainage. Figure (1) is an example of such encroachments.

In terms of the importance of protecting the Nile River in Egypt to satisfy the social and economic developments, this research was commenced with the main objective of investigating the encroachment impacts on the Nile flow characteristics and river morphology, where the 4th reach was taken as a case study. 


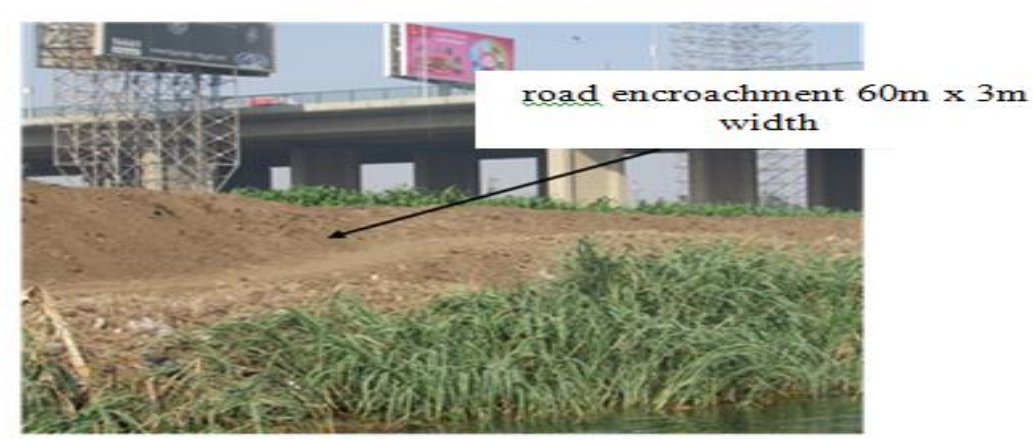

Figure(1): Citizens encroachment on the river floodplain

\section{OBJECTIVES}

In terms of the importance of protecting the 4th reach to satisfy the social and economic developments, this research was originated with the main objective of investigating the encroachment impacts on the flow characteristics and morphology of this reach.

\section{Accordingly, the sequential objectives were to:}

- Investigate the morphological changes during 2004-2014 by using 1-D model (i.e. GSTAR.

- Evaluate and compare the water level and the morphological changes of the 4th reach before and after encroachment using GSTAR.

\section{SITE DESCRIPTION}

The Nile is subdivided into four reaches. The 4th reach stretches from Assuit Barrage (i.e. 544.5 km D.S. Aswan Dam) till the Delta Barrage (i.e. 954.5 km D.S. Aswan Dam). This area was selected as a case study due to the availability of data to this specific reach; figure (2). 
J. Environ. Sci.

Institute of Environmental Studies and Research - Ain Shams University

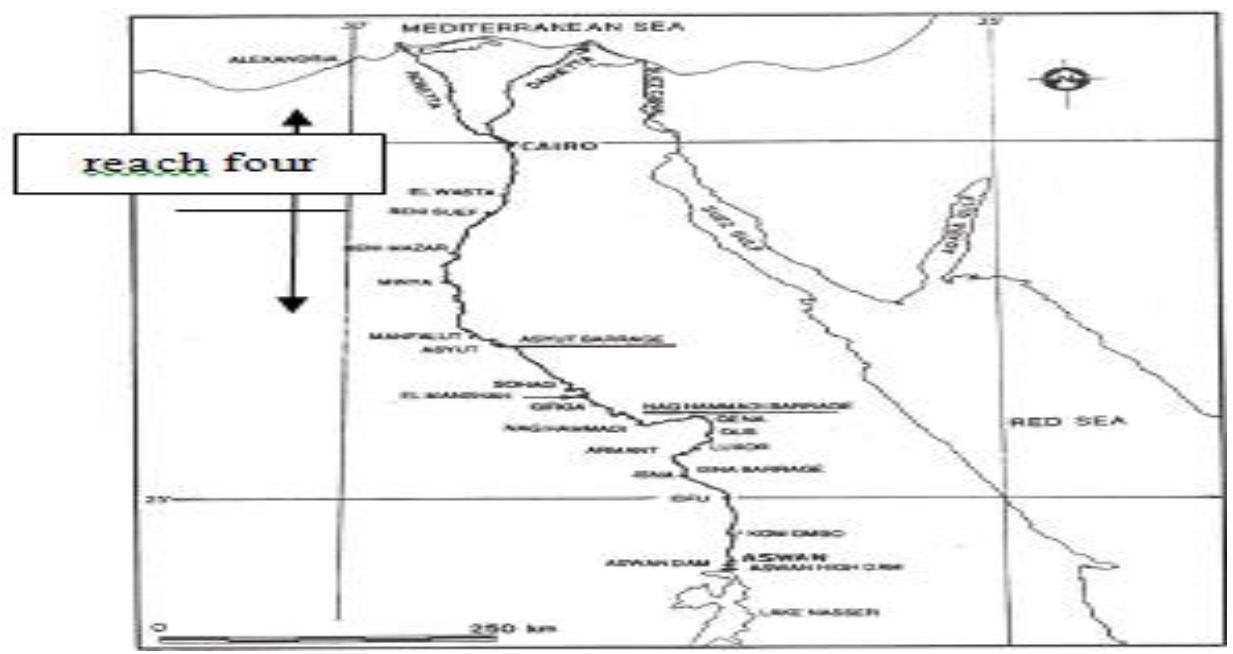

Figure(2): The River Nile barrages\& Reach Four

\section{A. THE ASSEMBLED DATA}

A.1 Hydrological data: Daily monitoring of discharges through the exiting hydraulic structures (i.e. barrages) and the corresponding water levels (at their U.S. so as D.S.) were assembled from different gauge stations. These data are listed in table (1).

Table(1): The gauges stations on the 4threach

\begin{tabular}{|c|c|c|c|c|c|}
\hline G. Station & $\begin{array}{c}\text { Distance } \\
(\mathbf{k m}) \\
\text { From AHD }\end{array}$ & G. Station & $\begin{array}{c}\text { Distance } \\
\mathbf{( k m )} \\
\text { from AHD }\end{array}$ & G. Station & $\begin{array}{c}\text { Distance } \\
(\mathbf{k m}) \\
\text { from AHD }\end{array}$ \\
\hline U/S Delta & 953.50 & Korimat & 839.15 & Menia & 687.55 \\
\hline Roda & 927.00 & $\begin{array}{c}\text { Bani } \\
\text { Suife }\end{array}$ & 808.60 & Mandra & 612.10 \\
\hline El Ekhsas & 888.35 & Beba & 789.00 & Maabda & 576.20 \\
\hline Lethy & 873.70 & Fadl & 735.25 & D.S Assuit & 544.78 \\
\hline
\end{tabular}

The minimum \& Maximum water level at D.S Assuit barrages( the inlet of reach four) at the period from 2000 to 2015 are 42.99 in 2007 and 49.5 in 
2004 as shown in Figure(3). the minimum\& Maximum water level at U.S Delta barrages (the outlet of reach four ) at the period from 2000 to 2015 are 15.25 in 2008 and 2009 and 17.09 in 2000 as shown in figure (4)

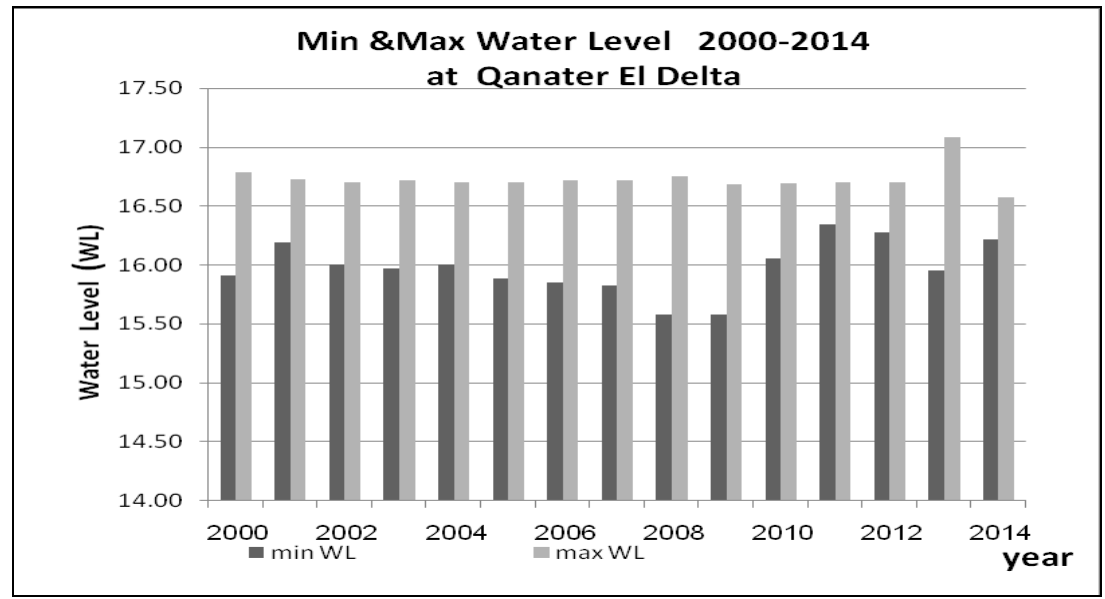

Figure (3): Maximum \& Minimum water level at D.S Assuit barrages during 2000-2014

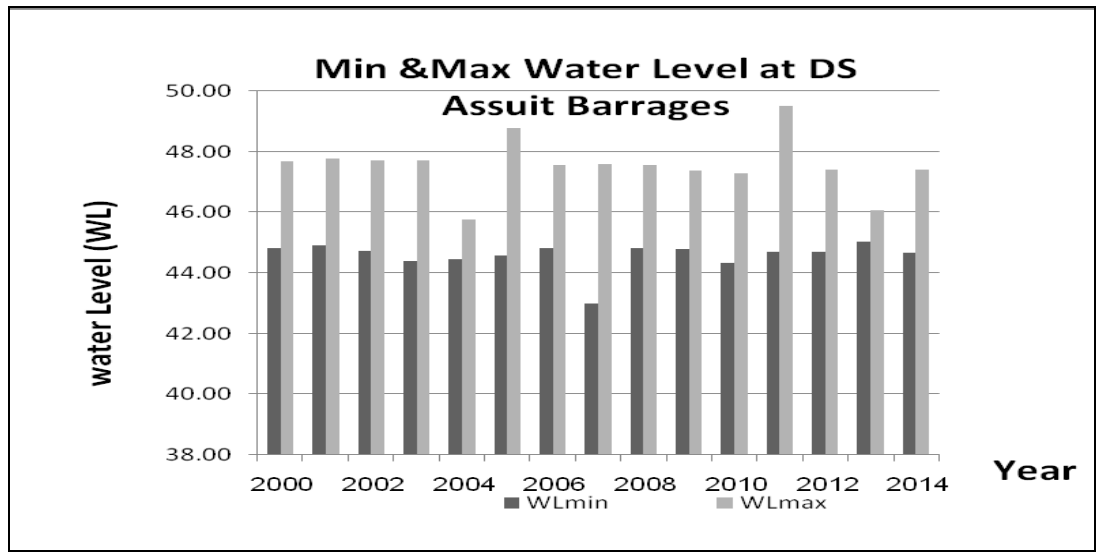

Figure(4): Maximum \& Minimum Water Levels at U.S Delta Barrage during 2000-2014 
A.2 Geometric Data: Geometric data was assembled using different techniques. among those was a hydrographic survey . This survey was carried out by Nile Research Institute "NRI" of the National Water

Research Center during 2004. The survey was carried out between the banks of the 4th reach to produce cross sections at $50 \mathrm{~m}$ interval spacing.

Moreover, These cross sections will be implemented in the mathematical model. The cross-sections, for the period 1982-1997, were obtained from contour maps using a software. These will be used in the mathematical model calibration. The cross-sections, for the period 1997to 2004, were obtained from contour maps using a software. These will be used in the mathematical model verification.

A.3 Roughness Coefficient: It is widely known that all water channels, from natural streambeds to lined artificial channels, exhibit water flow resistance, which is referred to as roughness. Hydraulic roughness is not necessarily identical to physical roughness. All hydraulic conveyance formulae evaluate roughness as a coefficient (i.e. Manning's Equation).

A proper n-value is difficult to determine and is critical in terms of engineering judgments, FHWA (1984).However, inexact and subjective nvalue determination might be identical in cross section with similar 
Table (2): Roughness coefficient at G, Station

\begin{tabular}{|c|c|c|}
\hline G. Station & Dist $\mathbf{( K m )}$ & Roughness Coefficient n \\
\hline U/S Delta & 953.5 & 0.03 \\
\hline Roda & 927 & 0.015 \\
\hline El Ekhsas & 888.35 & 0.05 \\
\hline Lethy & 873.7 & 0.05 \\
\hline Korimat & 839.15 & 0.04 \\
\hline Bani Swafe & 808.6 & 0.015 \\
\hline Beba & 789 & 0.03 \\
\hline Fadl & 735.25 & 0.0092 \\
\hline Menia & 687.55 & 0.0077 \\
\hline Mandra & 612.1 & 0.0129 \\
\hline Maabda & 576.2 & 0.016 \\
\hline
\end{tabular}

discharge and flow depth. Therefore, once the n-values are selected, no need to adjust them just to provide another answer. These assembled values were implemented in the present simulations.

\section{A.4 Morphological Changes Data During 1982 To 2004 :Morphological}

changes were determined from assembled cross-sections during 1982-19972004. These cross-sections reflected the overall changes of this reach. These changes were analyzed and presented on figures $(5,6)$. They designate the evident erosion and sedimentation across these sections. 
J. Environ. Sci.

Institute of Environmental Studies and Research - Ain Shams University

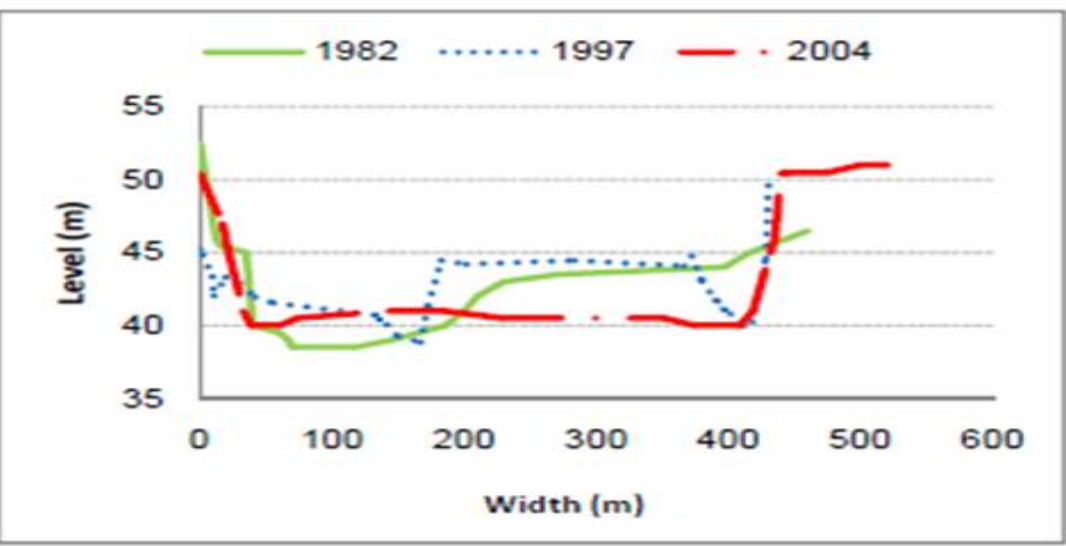

Figure(5): Cross-Sections at km (556.00) for the Years 1982,1997, 2004)

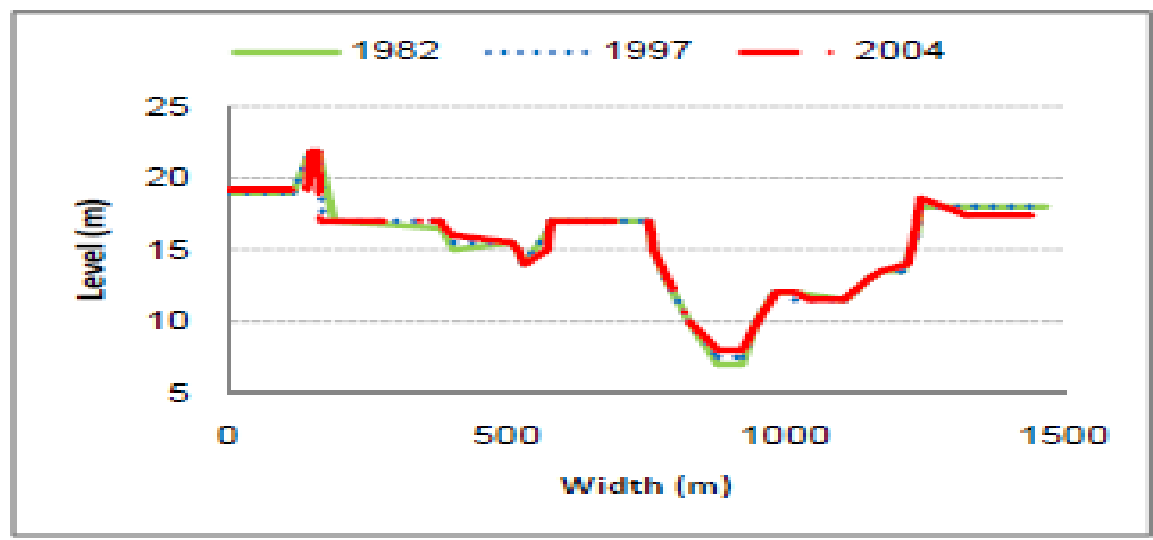

Figure(6): Cross-Sections at $948.00 \mathrm{~km}$ (years 1982, 1997 and 2004)

A.5 Encroachment Data: Encroachment data were assembled and analyzed. This is very pronounced in Egypt, where the Nile always experiences water stage fluctuations all through the year due to different released discharges from Aswan High Dam. These discharges change according to the planned daily requirements. Unfortunately, floodplains are uncovered during low stage time, which encourages commitment of encroachments on them. They 
are in the form of different developments (i.e. earth filling, construction or expansions of residents). Accordingly, they are tangibly affected during higher stages.

This paper will discuss the change of bed geometry according the encroachment; calculate the height scour so as sediment due to encroachment and evaluate the changes of geometry due to encroachment after a year. The assembled encroachment case, was the case of BeniSeuif Governorate, which is located at $808.6 \mathrm{~km}$ from Aswan Barrages and $263.82 \mathrm{~km}$ D.S Assuit Barrages. Table (4) is provided to summarize the encroachment cases along the 4 th reach during the same period. This encroachment pressents $30 \%$ of encroachments along the entire river.

Table(4): Summary of the No of encroachmentslocation along the 4th reach during 2010-2014

\begin{tabular}{|c|c|c|c|c|c|}
\hline year Governorate & 2010 & 2011 & 2012 & 2013 & 2014 \\
\hline Assuit & 46 & 60 & 148 & 170 & 90 \\
\hline Mania & 8 & 31 & 56 & 48 & 67 \\
\hline Beni Seuif & 68 & 160 & 681 & 603 & 105 \\
\hline Giza & 54 & 69 & 59 & 174 & 84 \\
\hline
\end{tabular}

As shown in table that the region is violated during 2011-2013 more than the year before (i.e. post 25th of January Revaluation) due to security absence. 
J. Environ. Sci.

Institute of Environmental Studies and Research - Ain Shams University

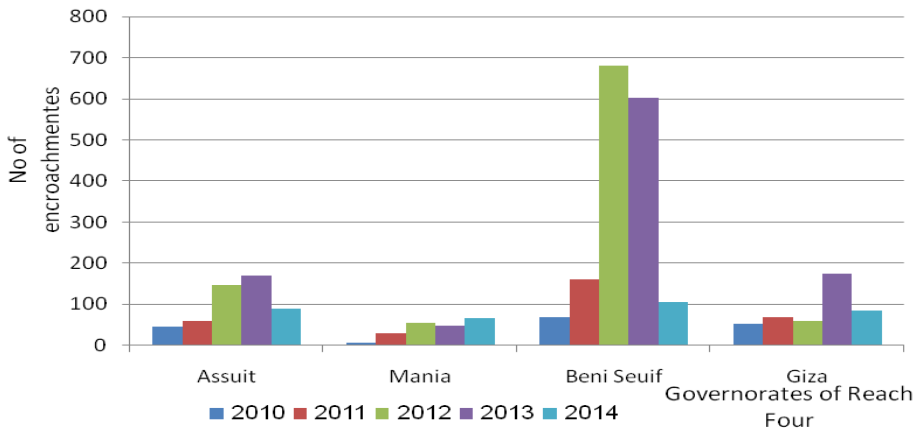

Figure(6): Number of encroachments in Reach Four from 2010 to 2014

The Improvement and Protection Sector in the Ministry of Water Resource is responsible for the encroachment removal. Table (5) is provided to list the frequencies of encroachment removal during 2010-2014. Moreover, photo (1) elaborates the encroachment evidence along the 4th reach in the different governorates.

Table(5): Frequencies of encroachment removal during 2010-2014

\begin{tabular}{|c|c|c|c|c|c|}
\hline Year Governorate & 2010 & 2011 & 2012 & 2013 & 2014 \\
\hline Assuit & 40 & 0 & 0 & 2 & 3 \\
\hline Menia & 6 & 8 & 4 & 10 & 20 \\
\hline Beni seuif & 87 & 21 & 0 & 3 & 6 \\
\hline Giza & 27 & 20 & 0 & 4 & 8 \\
\hline
\end{tabular}




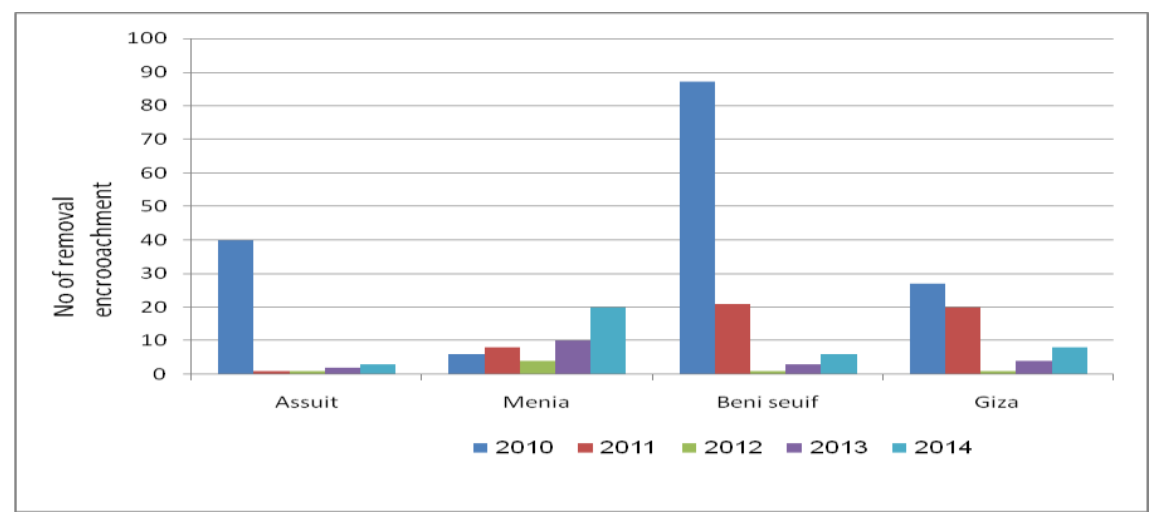

Figure(7): Number of removal encroachments in Reach Four from 2010 to 2014

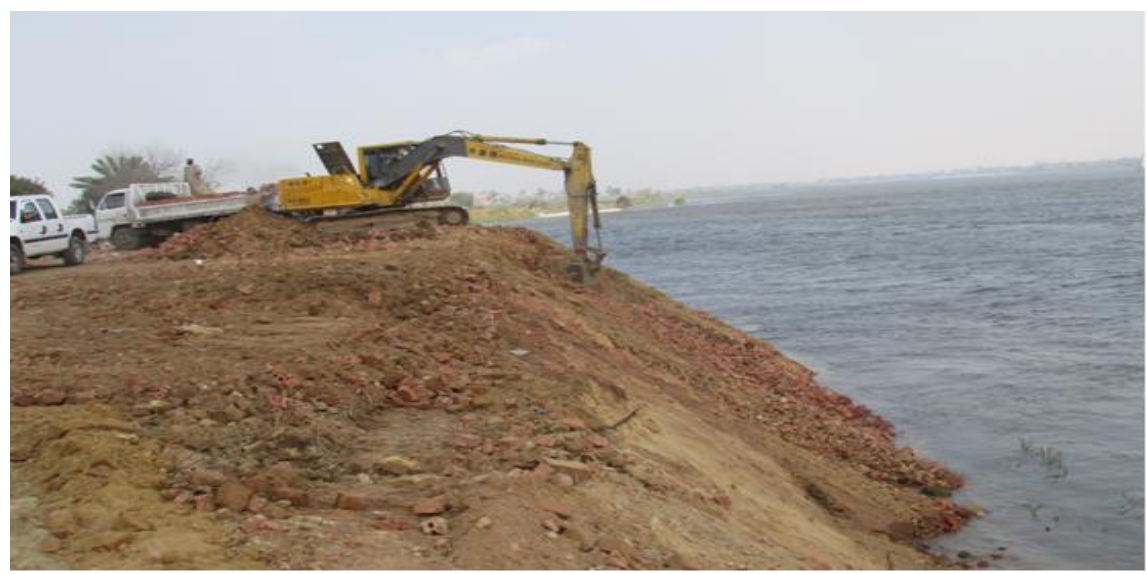

Photo (1): Removal of encroachment in BeniSeuif Governorate

\section{METHODOLOGY}

1 Selecting An Efficient Tool "Gstars" There are several available models that could simulate the 4 th reach. These models were inspected in order to select the most efficient model in terms of the available data, reach characteristics and research requirements. 
GSTARS "Generalized Stream Tube model for Alluvial River Simulation", which is a series of computer models developed by the U.S. Bureau of Reclamation. Yang C. T., et al. (2002) was selected to be implemented to model the reach under investigation.

GSTARS solve 1-D equation for each stream tube, independently, to obtain semi 2-D variation to hydraulic conditions along so as across stream tubes for rivers and reservoirs. Sediment transport, scour and deposition processes are simulated along each stream tube, independently, to give a semi 3-D variation of the bed geometry. GSTARS model applies minimum stream power theory for optimum channel width and channel geometry determination; figure (7).

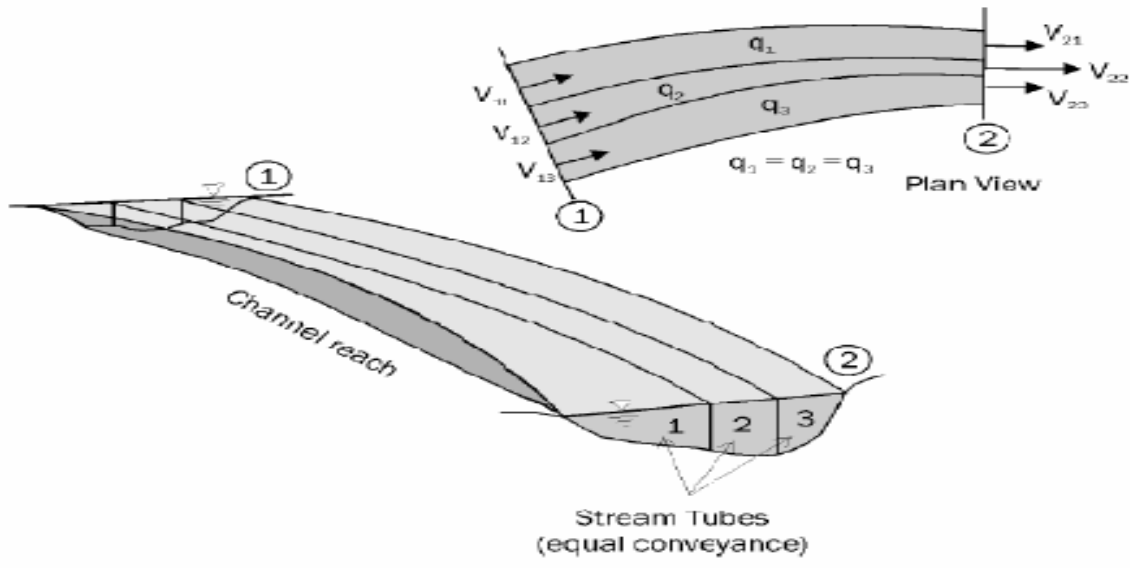

Figure (7): Schematic representation of stream tube concept

The basic water surface profile computational concept is based on solving the energy equation by the standard-step method, for subcritical flows, while Momentum Equation is used for supercritical flow. 
Solving both equations enables GSTARS to compute water surface profiles through sub-critical so as hydraulic jump at supercritical flows without interruption. GSTARS model is a quasi-steady flow model that represents unsteady hydrograph by a series of steps with constant discharge "Q" with a specified duration " $\Delta \mathrm{t}$ ".

This $\Delta \mathrm{t}$ could be chosen to provide accurate approximation to the hydrograph. GSTARS selects Manning, Chezy or Darcy-Weisbach formula in order to compute energy loss due to friction, contraction, expansion and local losses.

GSTARS has several available sediment transport formulas. Their basic concept conservation of sediment equation that is given as follows:

$\partial \mathrm{QS} \partial \mathrm{Ad} \partial \mathrm{As}$

$$
-+\eta-+- \text { - q lat }=0
$$

$$
\partial \mathrm{x} \quad \partial \mathrm{t} \quad \partial \mathrm{t}
$$

\section{Where:}

$\eta=$ volume of sediment in a unit bed layer volume (one minus porosity)

$\mathrm{Ad}=$ volume of bed sediment per unit length

As $=$ volume of sediment in suspension at the cross section per unit length

Qs= volumetric sediment discharge

q lat= lateral sediment inflow

In this research was used three equations from the eleven Sediment transport concept. three equations are (Engelund and Hansen's 1972 approach -Ackers and White (1973) Formula -parker's 1990 method ) 
J. Environ. Sci.

Institute of Environmental Studies and Research - Ain Shams University

\section{RESULTS AND ANALYSIS}

This paper presents the results of GSTARS and the serious impacts of encroachment on the different characteristics of the reach (i.e. changes of the alluvial channel profile and cross sectional geometry). In addition, the impact of encroachment on morphology on the 4th reach. Moreover, some applications are discussed (i.e. bank overtopping and planning of navigational channel).

1. Impact of Flow Mode: 30 sections was surveyed by the Nile Research Institute (NRI), where encroachment was evident in Beniseuif and El Mania Governorates. Three scenarios were selected to be simulated. The selection was based on period from 2004 to 2014, where the discharges were 37.5,140 and 180 M.m3/day compared with the rating curve result which made by NRI and the future plan of the Ministry of Water Resources and Irrigation to pass up to $350 \mathrm{M} . \mathrm{m} 3 /$ day and the amount in between the minimum and maximum is 140 M.m3/day.

2. Impact of Flow Mode Due To Encroachment: The analysis of cross sections geometry changes is presented on the following figures. Figure (V.1) indicates that the encroachment effect was apparent at cross sections with higher water levels (i.e.from $65 \mathrm{~km}$ to $135 \mathrm{~km}$ ). This is the region where serious impact were evident in Beni seuif Governorate.the figure (V.1) the water level rise in the distance from 64 to $133 \mathrm{~km}$ which located in beni seuif the region was occured the encroachment and human interventions the water level rise from 6 to $45 \mathrm{~cm}$. 


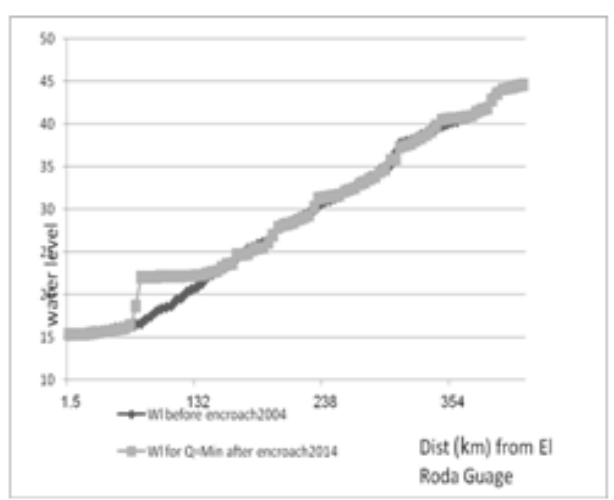

Figure ( 8.1) Water level at minimum discharge $\mathrm{Q}=37.5 \mathrm{M} . \mathrm{m} 3 /$ day

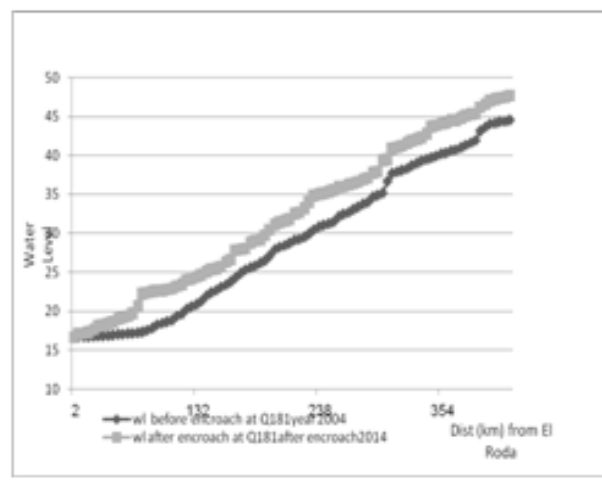

Fig (8.3) Water Level at minimum discharge $\mathrm{Q}=181 \mathrm{Mm} 3 /$ day

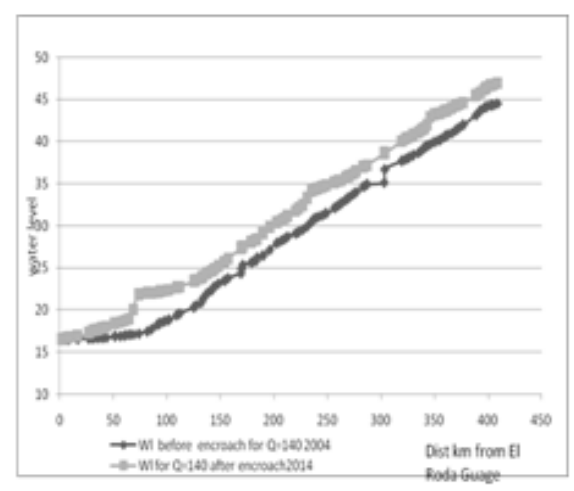

Fig ( 8.2 ) Water Level at discharge $Q=140 \mathrm{Mm} 3 /$ day

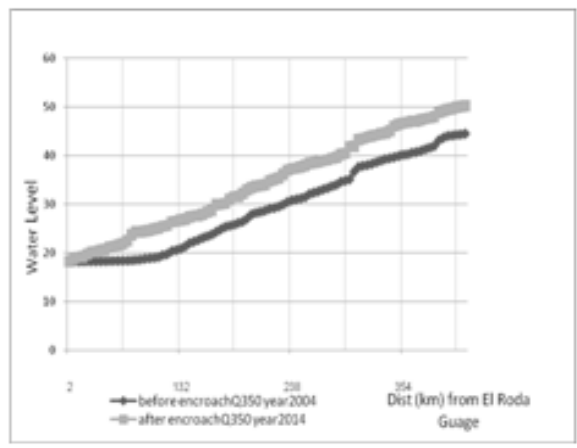

Fig (8.4) Water Level at Maximum discharge $Q=350 \mathrm{Mm} 3 /$ day

From figures shows that the encroachment effect on water level along reach four that the water level rose in all section as mention before the human intervention almost made the encroachment in high elevation which appear in high discharge Water level rose by $6-45 \mathrm{~cm}$

3. Analysis Of Cross Sections Geometry: The cross sections geometrychange due to the encroachment in specific distances along 4th reach is 
discussed .In this case we studied the effect of encroachment on the morphology of River Nile into two cases ( the flow Discharge and sediment ) through three scenarios of Discharge the minimum discharge which flowing in period of minimum water needs -the normal discharge which already flow in the stream - the maximum discharge which flowing in the period of maximum water needs.

3.1 Analysis of cross sections Geometry: In this case study impact of flow on change the water level due to encroachment occurred

At Minimum Discharge( 37.5M.m3/day): This scenario is the minimum discharge which flow in the stream and study the impact of encroachment on sections on Reach four .this is example of that case .

The effect of filling encroachment on the River Nile in order to cultivate the land throughout the year rather than seasonally cultivated has no effect of water level because the encroachment is out of water section but it effects on top width by decreasing it from 330 (p1) to 180 (p2) which affect on the sections coming after this section and accelerate the velocity in this section

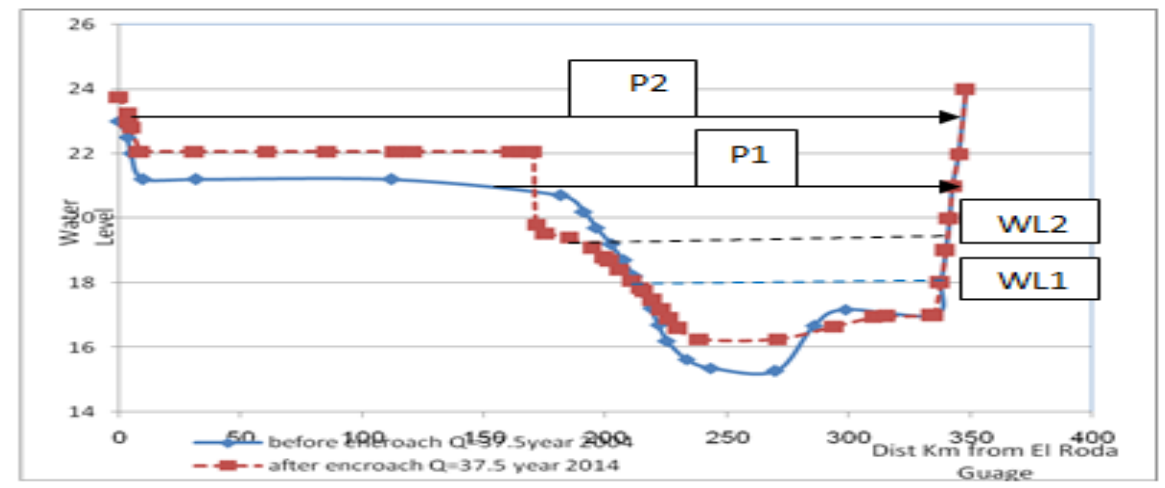

Fig(9): Water Level at 133. 506Km before and after encroachment 
At Normal Discharge $(Q=181$ M.m3/day): This scenario is the normal discharge which already flow in the stream and study the impact of encroachment on sections on Reach four this is example of that case .

the section below had effected from the encroachment occurred in figure 9 so the section participated as well as have shifted up by $50 \mathrm{~cm}$ and the water level increase by $30 \mathrm{~cm}$ due to the change of the section occurred

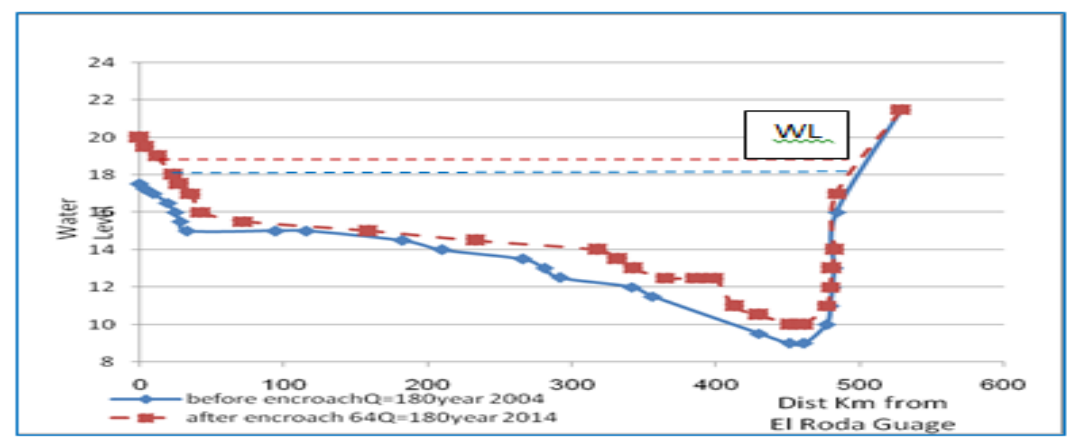

Fig(10): cross section at $64.503 \mathrm{Km}$ before and after encroachment

\section{At Maximum Discharge $(Q=350$ m.m3/day):}

This scenario is the maximum discharge which flow in the stream and study the impact of encroachment on sections on Reach four this is example of that case

As shown in figure (11) the water level icreases by $104 \mathrm{~cm}$ according to the encroachment and due to decreases of top width with maximum flow which predicate that location will sink in future with maximum flow 
J. Environ. Sci.

Institute of Environmental Studies and Research - Ain Shams University

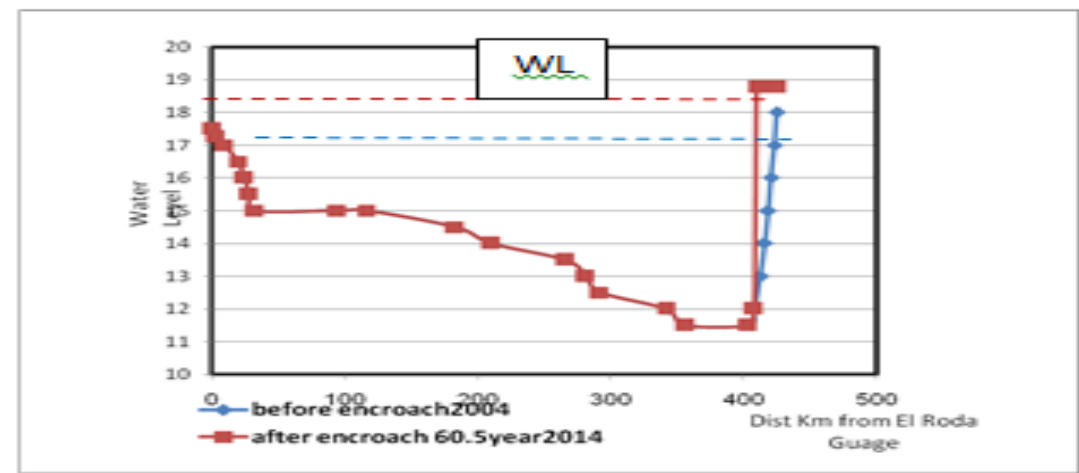

Fig.(11): cross section at $60.513 \mathrm{Km}$ before and after encroachment

3.2 Analysis of Morphology:- In this case study impact of morphology on change of the sediment due to encroachment occurred

At Minimum Discharge( 37.5M.m3/day): This scenario at minimum discharge which already flow in the stream at the period of minimum water needs (from September to December), study the impact of encroachment on sections along Reach

From figure 12:the encroachment increase the top width of the section from $\mathrm{p} 1$ to $\mathrm{p} 2$ which increase the cross section as balance equation $\mathrm{A} 1 \mathrm{~V} 1=\mathrm{A} 2 \mathrm{~V} 2$ so the velocity of the section after encroach increase which made sediment for neighbor section and effect of change the velocity impact on the section by sediment on part of the section 

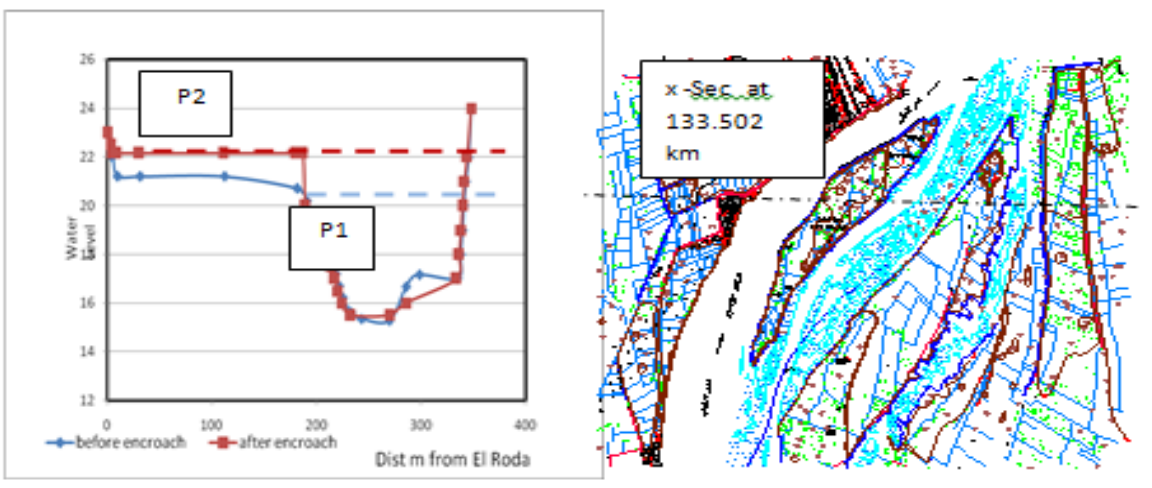

Fig (12): cross section at $1^{r r} .506 \mathrm{Km}$ before and after encroachment

At Normal Discharge $(Q=181$ M.m3/day): This scenario at normal discharge which already flow in the stream, study the impact of encroachment on sections along Reach four .this is example of that case

this section change absolutely from before to after encroachment the section shifted up by $50 \mathrm{~cm}$.the section hasn't encroachment but the section effected by encroach occurred before this section as mentioned before

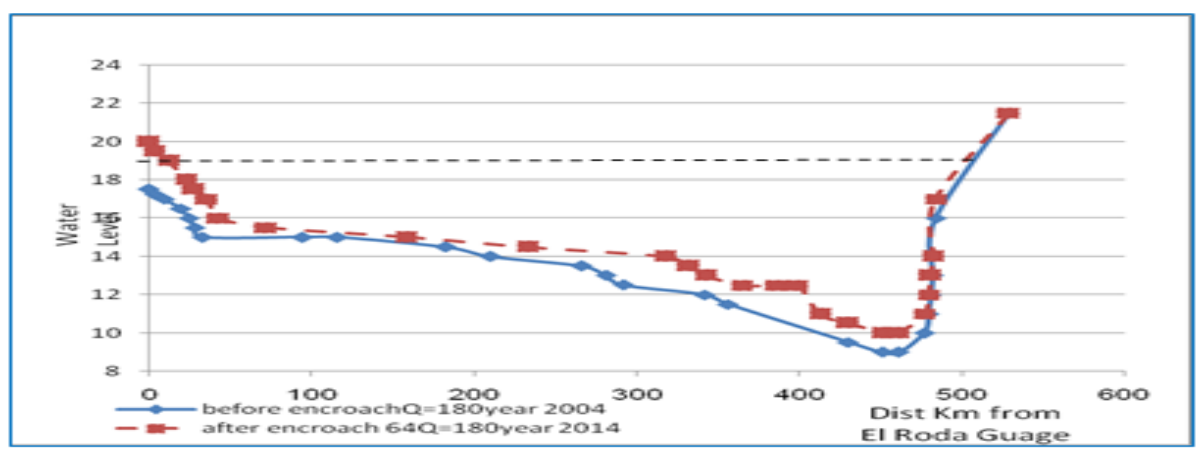

Fig (13): Water Level at $\Upsilon \leqslant .503 \mathrm{Km}$ before and after encroachment 
At Maximum Discharge $(Q=350$ m.m3/day $):$ This scenario at maximum discharge which flow in the stream at the period of maximum water needs (from September to December), study the impact of encroachment on sections along Reach four this is example of that case .

due to the change occurred in the stream according to the encroachment happened this section has sediment by average $50 \mathrm{~cm}$ deep along the all section not only due to encroachment but also result to the change of morphology which happened due to the encroachment this section has not encroach but change occurred due to violence on the stream in the sections after and before

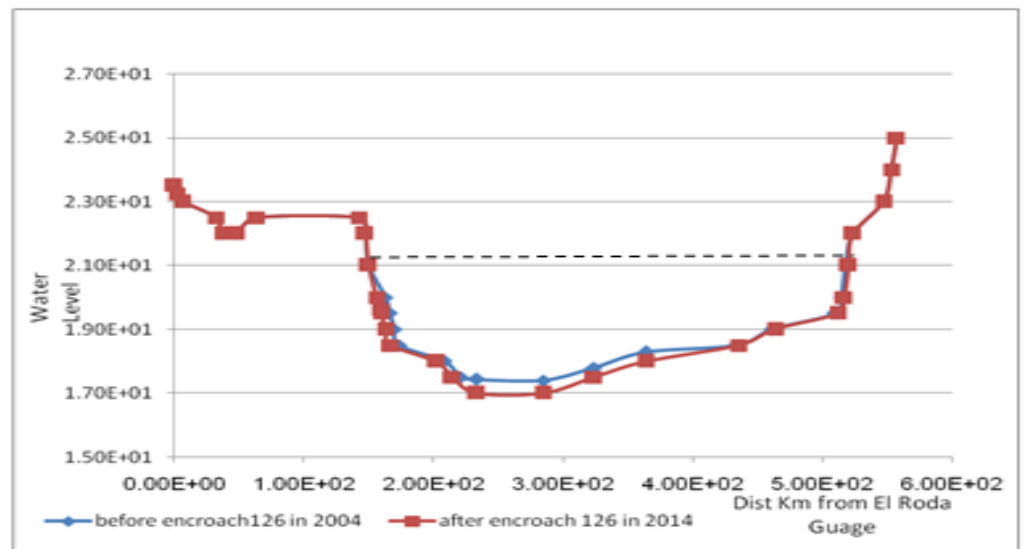

Fig.(14): Water Level at $126.512 \mathrm{Km}$ before and after encroachment

3.3. the impact of encroachment after one year on Morphology: This case is to predicate what happened in stream along Reach four after one year from encroach happened in different Discharge ( 37.5-181-350 m.m3/day) but in case of sediment properties 
At Minimum Discharge( 37.5M.m3/day): This scenario at minimum discharge which already flow in the stream at the period of minimum water needs (from September to December), study the impact of encroachment on sections along Reach four after one year from encroachment happened .this is example of that case .

The left side of the section change after one year which create new bank that mean the encroachment affect on morphology of the stream

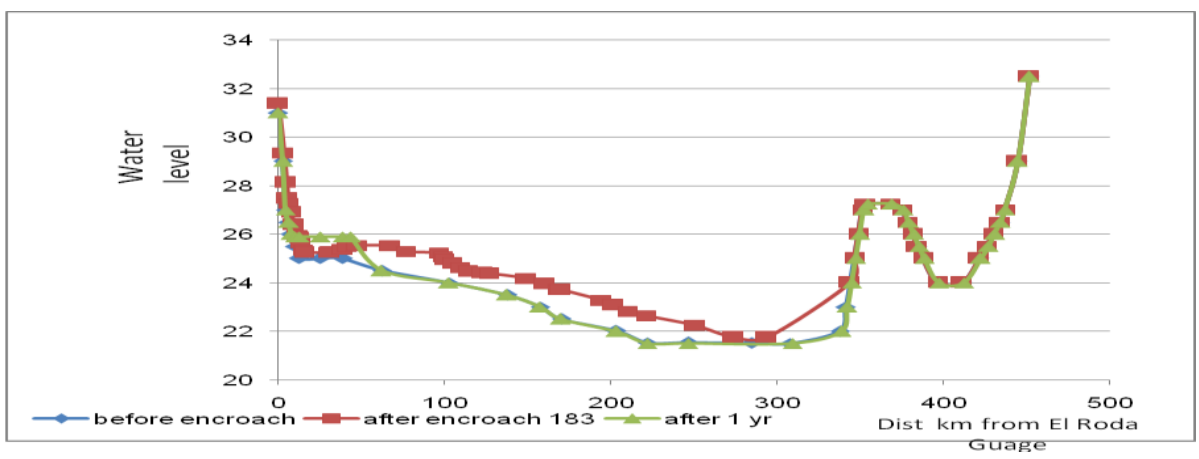

Fig(15): Water Level at $182.516 \mathrm{Km}$ before and after encroachment

At Normal Discharge $(Q=181$ M.m3/day): This scenario at normal discharge which already flow in the stream, study the impact of encroachment on sections along Reach four after one year from encroachment happened .this is example of that case .

Fig (16): this section in sediment region because there are meandering this appear in this section after passing one year 
J. Environ. Sci.

Institute of Environmental Studies and Research - Ain Shams University

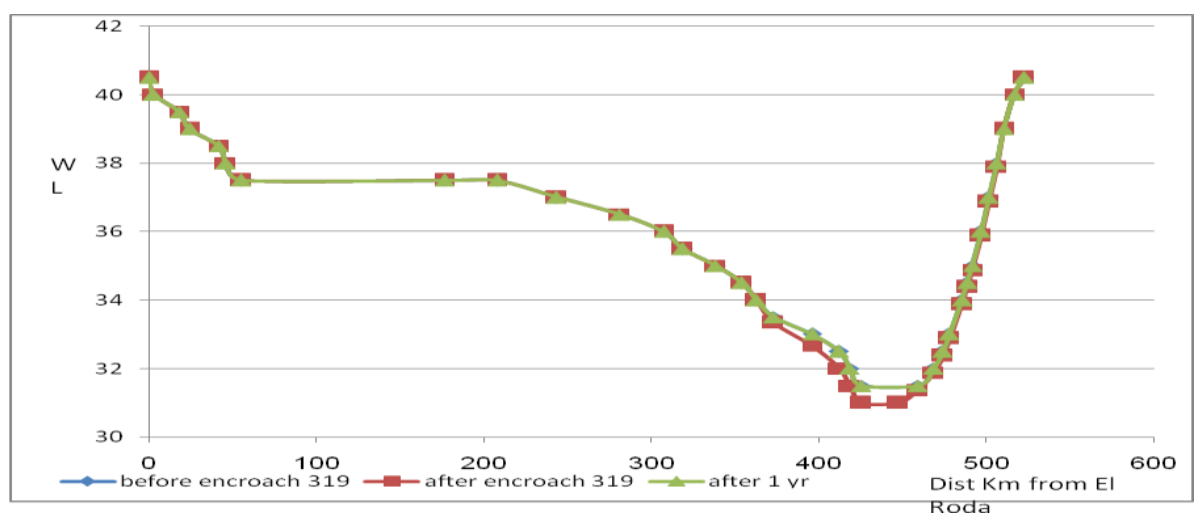

Figure(16): at $319.515 \mathrm{~km}$ from El Roda Guage

At Maximum Discharge $(Q=350$ m.m3/day $):$ This scenario at maximum discharge which flow in the stream at the period of maximum water needs (from September to December), study the impact of encroachment on sections along Reach four after one year from encroachment this is example of that case .

Figure 17: the section after passing one year from encroachment occurred the same as well as encroachment ocurred now which mean the maximum flow cann't remove the violance and it needs the effort of the ministry to remove it as doing now 
Ali,, et al

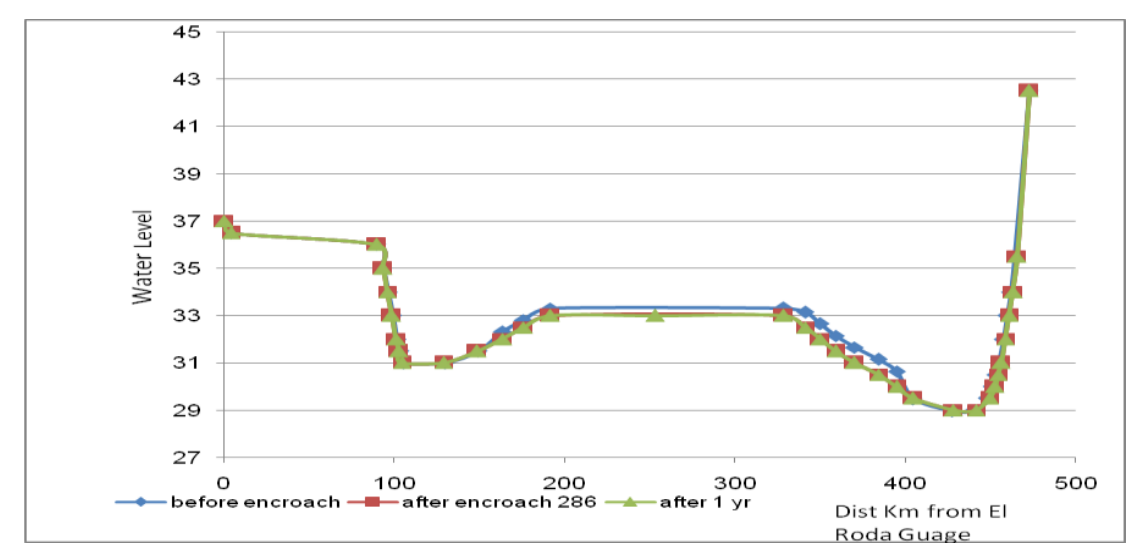

Fig.(17): at $286.516 \mathrm{Km}$ after one year of encroachment

\section{CONCLUSION}

Based on the results of the present investigation, the following conclusions were deduced:

1. The implemented 1-D model is capable of elaborating the encroachment impacts by computing the water surface profile and cross section changes during 2004-2014.

2. From study the impact of encroachment on the reach four found that Beni seuif Governorate is the most Governorates affected from the encroachment which located from 102 to $164 \mathrm{~km}$

3. At minimum discharge flowing:

- The most locations are affected of the encroachment which it appears from 60.5 to $334.5 \mathrm{~km}$

- some locations are deposition from $334.506 \mathrm{~km}$ to $268.513 \mathrm{~km}$

- Other locations are scoured from 168.513 to $266.305 \mathrm{~km}$

4. At maximum discharge flowing: 
- Some locations will be flooded in future ( from $286.512 \mathrm{~km}$ to 129.503 $\mathrm{km})$

- Other locations will be sediment from $133.517 \mathrm{~km}$ to $73.503 \mathrm{~km}$

5. The bad effect of stream due to encroach cleared in island which give the violence chance to use it and build on it

\section{RECOMMENDATIONS}

Based on the above conclusions, the following recommendations were suggested for the Engineering practice so as future studies:

- Remove the encroachment to remove the bad effect due to violence which already the ministry of water resource and irrigation began to removing it

- Protect the lower level by biding with stones to not to give the violence chance to encroach

- Protect the side of island to prevent the violence from encroach

- Protect the sites of lower level which discovered when the water level decrease to prevent the violence from encroach

- The researcher should study the impact of encroachment due to bridge which had critical effect on morphology of the stream and impact with encroachment

- Increase the following on the stream to prevent the violence made encroachment and enlarge the tax for people already encroached 


\section{REFRENCES}

Coppin, P. \& Bauer, M. (1996): Digital Change Detection in Forest Ecosystems with Remote Sensing Imagery. Remote Sensing Reviews.13, 207-234.

Elhag, A. M. H. (2003) Assessment of Sand Encroachment Using Remote Sensing and GIS: Case Study Dongola Area, Sudan. PhD. thesis, University of Khartoum, Sudan.

Hamad, O. E. and El-Battahani, A. (2005): Sudan and the Nile Basin. Aquatic Science. 67, 28 - 41.

Moussa.A.M.A (2002): Nile River morphology expected changes due to abnormal flows. Damietta branch. PhD. thesis, University of Ain Shams, Egypt

Moussa. A.M.A. (2010): Morphological Analysis for Reach Four of the Nile River from 1982 to 2004 Using Rating Curves and Hydraulic Geometry Parameters, scientific bulletin, Ain Shams .

Richard, J. A. \& Kelly, D. J. (1984): On the Concept of Spectral Class. International Journal of Remote Sensing. 5.(6), 987-991.

Robinove, C.J. (1981): The logic of Multispectral Classification and Mapping of Land. Remote Sensing of Environment. 11, 231-244.

Singh, A. (1989): Digital Change Detection Techniques Using Remotely Sensed Data. International Journal of Remote Sensing. 10,(6), 989-1003

UNESCO Chair in Water Resources-Sudan, 2001 Report on Magnitude of Sand Encroachment on the Nile in Sudan. Khartoum,

Van der Kevie, W. (1976): Climatic Zones in the Sudan. Bulletin No. 27. Soil Survey Administration, Wad Medani, Sudan. 


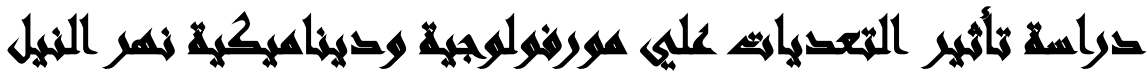

\section{[r]}

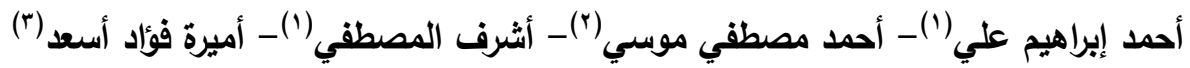

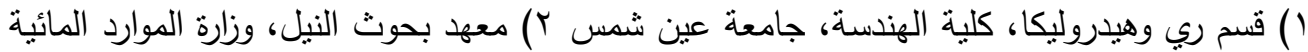
والري ؟) وزارة الموارد المائية والري الري

\section{المستخلص}

تعد الأنهار مركز الأنشطة البشرية طوال العصور القديمة والحديثة في جميع أنحاء العالم

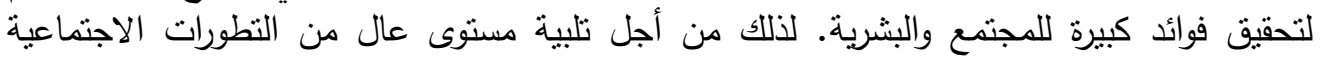

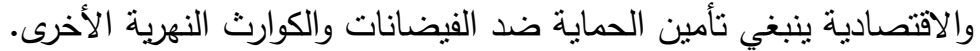

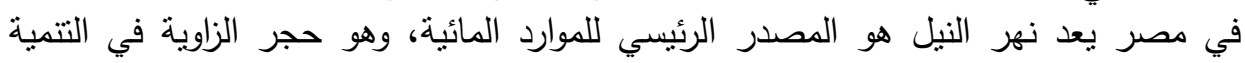

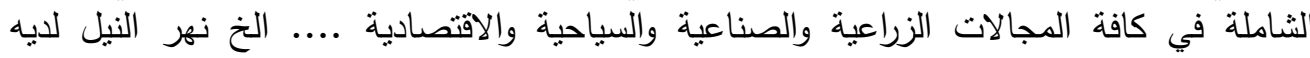

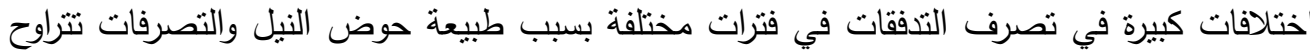

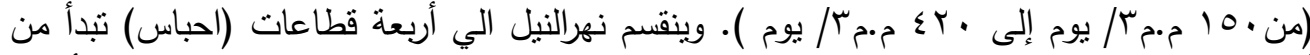

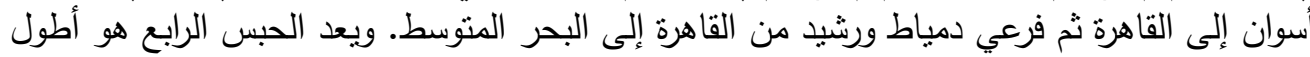

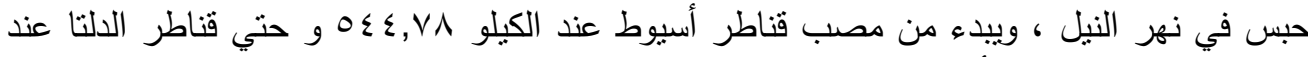

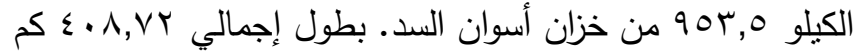

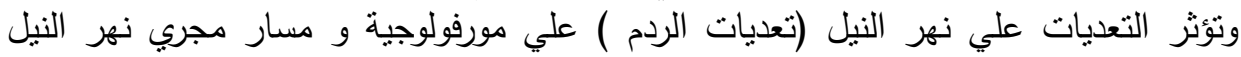

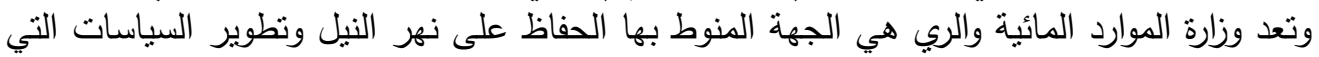

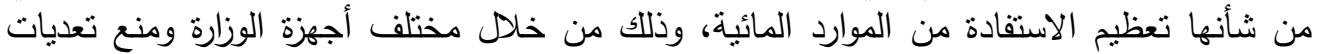

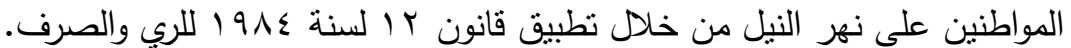

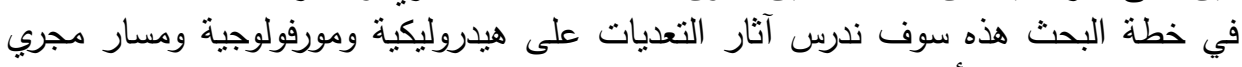

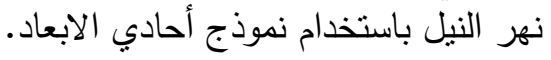

